\title{
The petrology and petrogenesis of the North Motzfeldt Centre, Gardar Province, South Greenland
}

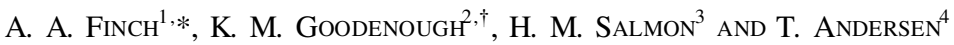 \\ ${ }^{1}$ Crustal Dynamics Group, School of Geography and Geosciences, University of St Andrews, St Andrews, Fife \\ KY16 9AL, UK \\ ${ }^{2}$ Department of Geology and Geophysics, University of Edinburgh, West Mains Road, Edinburgh EH9 3JW, UK \\ ${ }^{3}$ School of Earth Sciences, Birkbeck College, University of London, Malet Street, London, WC1E 7HX, UK \\ ${ }^{4}$ Laboratory of Isotope Geology, Geologisk Museum, University of Oslo, Sarsgate 1, Oslo N-0562, Norway
}

\section{ABSTRACT}

North Motzfeldt is an intrusive igneous centre within the Igaliku (formerly spelt Igaliko) complex, Gardar Province, South Greenland. A detailed field description of the centre is given, with preliminary geochemical and isotopic data. The North Motzfeldt centre is intruded into Ketilidian granitoid basement rocks, and current exposure retains parts of the original roof against earlier Gardar eruptives and clastic sediments of the Eriksfjord formation. The unconformity between the Ketilidian and the overlying Eriksfjord is believed to have been crucial in the siting of the centre. The centre is subdivided into two major units, NM1 and NM2. This was followed by significant peralkaline nepheline microsyenite in sheets, characterized by rare element-rich accessory minerals including rinkite- $\mathrm{m}$ sandrite, pyrochlore and låvenite. A significant microsyenite body is called NM3. A preliminary $\mathrm{Rb}-\mathrm{Sr}$ isochron of $1226 \pm 27 \mathrm{Ma}$ indicates a far younger age for the centre than previously thought ( $1350 \mathrm{Ma})$. Cross-cutting relationships between North Motzfeldt and rocks of the adjacent Motzfeldt centre require a reappraisal of the chronology of Motzfeldt magmatism. We suggest that rocks previously believed to comprise the Motzfeldt centre represent the products of multiple phases of magmatism from Early- to Mid-Gardar times.

KEYwoRDs: Gardar, Ketilidian, nepheline syenite, magma chamber, roof zones.

\section{Introduction and geological setting}

THE 'Gardar Province' is the name given to the products of alkaline magmatism associated with continental rifting in southern Greenland in Proterozoic $(\sim 1350-1150 \mathrm{Ma})$ times. It comprises about a dozen plutonic centres, together with lavas (the Eriksfjord Formation), dyke swarms and 'giant-dykes'. Gardar rocks

\footnotetext{
* E-mail: aaf1@st-and.ac.uk

${ }^{\dagger}$ Present address: British Geological Survey, Murchison House, West Mains Road, Edinburgh, EH9 3LA, UK

* The spelling of Greenlandic place names was revised by the Greenland Government in the 1980s and new spellings are used throughout the present article. Where a change in spelling was recommended, the old spelling is indicated at the first mention.
}

DOI: $10.1180 / 0026461016560007$ range in composition from picrite, through alkali basalt and alkali gabbro, to alkali granite, nepheline syenite and agpaitic compositions. Recent glaciation has exposed excellent unvegetated vertical and horizontal sections through Gardar structures, with the result that the Gardar is recognized as among the best-exposed igneous provinces in the world.

Gardar activity has been divided into three periods termed early, mid and late Gardar (see Upton and Emeleus, 1987, and Emeleus and Upton, 1976 for reviews). Much of our understanding of the Early Gardar comes from field mapping and radiometric age dating associated with the NE Gardar around the major syenite complex of Igaliku (previously spelt Igaliko ${ }^{\ddagger}$ ). The Igaliku complex (Emeleus and Harry, 1970) comprises $\sim 250 \mathrm{~km}^{2}$ of augite and nepheline syenite exposed to the $\mathrm{NE}$ and $\mathrm{E}$ of Igaliku 

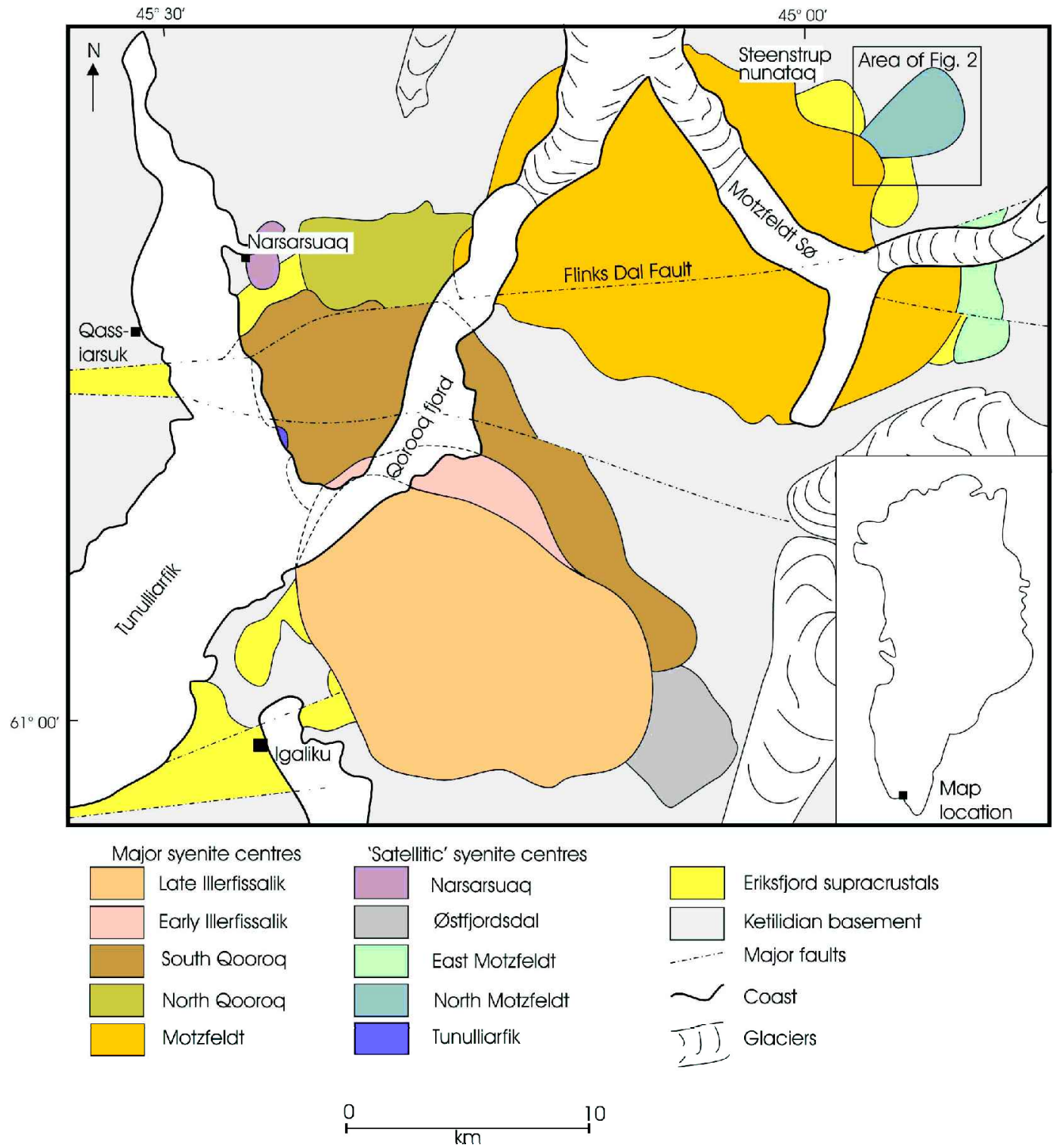

FIG. 1. Location of the Igaliku Complex.

village (Fig. 1) which has been active over $200 \mathrm{Ma}$ (Upton and Emeleus, 1987). Igaliku has been subdivided into five main plutonic centres and various satellite intrusions (Table 1), although some adaptations to this scheme have been suggested. In the area around a satellitic intrusion termed North Motzfeldt (Fig. 1), there are exposures of what is believed to be the earliest eruptives and the oldest plutonic centre (the North
Motzfeldt syenites) in the province. North Motzfeldt plays a pivotal role in our understanding of the early development of the Gardar rift.

The present study describes the field relationships, and presents a petrological and geochemical description of the North Motzfeldt syenites, a small $(4 \times 3 \mathrm{~km})$ plutonic centre within the Igaliku Complex. Tukiainen (1988 and references therein) revised the nomenclature of Emeleus 
TABLE 1(a). Summary chronology of emplacement events in the Igaliku Complex.

\begin{tabular}{lll}
\hline Name & \multicolumn{1}{c}{ Description } & \multicolumn{1}{c}{$\mathrm{Rb}-\mathrm{Sr}$ ages } \\
\hline Early Motzfeldt centre & Gabbro, nepheline syenites and lujavrite & $1282 \pm 30 \mathrm{Ma}$ \\
& & $(1350 \pm 10 \mathrm{Ma}$ by U-Pb on apatite $)$ \\
North Qooroq centre & Nepheline syenites and lujavrite & $1268 \pm 60 \mathrm{Ma}$ \\
North Motzfeldt & Nepheline syenites & $1226 \pm 27 \mathrm{Ma}$ \\
East Motzfeldt & Nepheline syenite & None \\
Late Motzfeldt centre & Nepheline syenites & None \\
Østfjordsdal syenite & Nepheline syenite & None \\
Narsarsuaq* syenite & Nepheline syenite & None \\
Tunulliarfik* syenite & Nepheline syenite & None \\
South Qooroq centre & Augite and nepheline syenites & $1160 \pm 8 \mathrm{Ma}$ \\
Early Illerfissalik* centre & Augite and nepheline syenites & None \\
Igaliku Dyke swarm & Picrites to phonolites & None \\
Late Illerfissalik* centre & Gabbro, augite and nepheline syenites & $1142 \pm 15 \mathrm{Ma}$ \\
& &
\end{tabular}

Oldest events are placed at the top of the table and the youngest at the bottom. Radiometric age dates are taken from Upton and Emeleus (1987) and the present work. The U-Pb age for Early Motzfeldt is from Paslick et al. (1993). Major intrusive centres are highlighted in bold.

* Modern spellings are used throughout the present study. Previous spellings were Igaliku = 'Igaliko', Illerfissalik = 'Igdlerfigssalik', Narsarsuaq = 'Narssarssuaq', Qooroq = 'Qôroq', Tunulliarfik = 'Tunugdliarfik'

TABLE $1 b$. Chronology of events in the development of the North Motzfeldt region.

\begin{tabular}{lll}
\hline Name & \multicolumn{1}{c}{ Description } & \multicolumn{1}{c}{ Isotopic ages } \\
\hline Ketilidian Basement & Hornblende Diorites and Granites & $1799 \pm 2 \mathrm{Ma}^{1}$ \\
Eriksfjord Formation & Trachytic Eruptives and Clastic Sediments & None \\
North Motzfeldt units & Nepheline syenites & $\mathbf{1 2 2 6} \pm 27 \mathrm{Ma}^{2}$ \\
?E-W dykes & Thin Green Trachytes & None \\
Late Motzfeldt centre & Nepheline syenites & None \\
Igaliku dyke swarm & Basalts, trachytes and phonolites & None \\
Faulting & $\mathrm{N}-\mathrm{S}, \mathrm{E}-\mathrm{W}$ and NW-SE faulting identified & None \\
& & \\
\hline
\end{tabular}

Oldest events are placed at the top of the table and the youngest at the bottom. The North Motzfeldt syenites are highlighte d in bold

References: 1 - Garde et al. (2001), 2 - this work

and Harry (1970) for the Motzfeldt and North Motzfeldt centres, and classed the North Motzfeldt syenites with nepheline syenites in the north of Motzfeldt as part of the 'Geologfjeld Formation'. They also included the adjacent East Motzfeldt syenite with other Motzfeldt rocks as a part of the 'Motzfeldt Sł Formation'. The North Motzfeldt syenites, which we identify as a distinct igneous centre, with the country rocks around them, form the focus of the present study.

\section{Previous research in the North Motzfeldt area}

The Motzfeldt centre, which comprises a series of nested nepheline syenite intrusions and ringdykes, has been studied by Emeleus and Harry (1970), Jones (1980, 1984), Jones and Peckett (1980), Tukiainen et al. (1984), Armour-Brown et al. (1983), Jones and Larsen (1985), Tukiainen (1988), Finch (1990a,b) and Finch et al. (1995). The North Motzfeldt syenites (Fig. 2) were first 


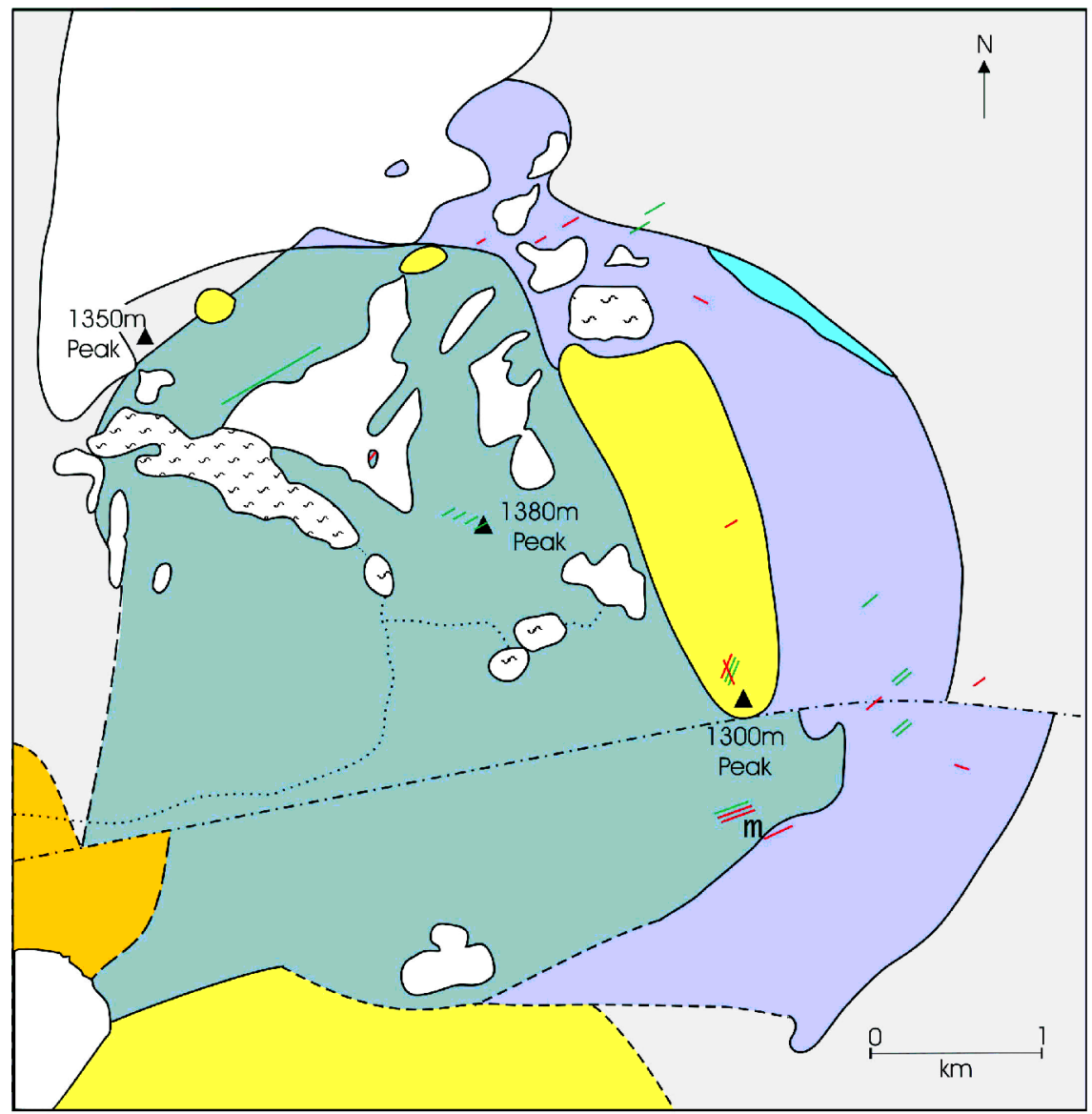

North Motzfeldt Syenites

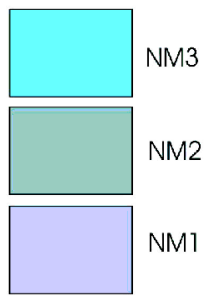

m Significant microsyenite sheeting

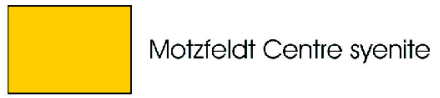

Eriksfjord supracrustals (undifferentiated)

Ketilidian basement
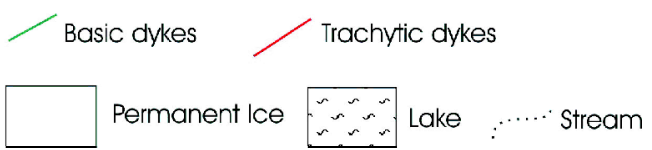

FIG. 2. Map of the North Motzfeldt Centre. The colour scheme is after Emeleus and Harry (1970).

noted during reconnaissance mapping of the Igaliku area by the Geological Survey of Greenland (Emeleus and Harry, 1970) and were considered to represent a satellitic intrusion to the Motzfeldt centre. North Motzfeldt rocks are exposed in an area of $\sim 4 \mathrm{~km}$ by $3 \mathrm{~km}$ on a nunataq to the NE of Motzfeldt Sł (sometimes termed 'Steenstrup nunataq', Fig. 1). The country rocks in this area belong to the Julianehåb Batholith, part of the Ketilidian mobile belt, 
which has been described by Allaart (1976), Chadwick and Garde (1996), Garde et al. (1998) and Grocott et al. (1999). These are generally biotite granites with some regions of granodiorite. In addition, there are intermediate to basic enclaves up to a few $\mathrm{km}$ in size and dykes of appinite affinity. The Julianehåb granite has a range of U-Pb ages spanning 1880 to $1790 \mathrm{Ma}$ (Garde et al., 1998). There are no precise radiometric age determinations for the Julianehåb batholith in the Motzfeldt region, but a Ketilidian aplitic feldspar porphyry from Johan Dahl Land to the NW has been dated at $1799 \pm 2$ Ma (Garde et al., 2001). The Ketilidian basement in the study area is therefore probably $\sim 1800$ Ma old.

Emeleus and Harry (1970) noted that the contact between the North Motzfeldt syenites and the nepheline syenites of the Motzfeldt centre is not exposed, but that field relations indicate that the North Motzfeldt syenites are older than those of Motzfeldt. They also commented that the North Motzfeldt syenites are cut by Gardar dykes of the Igaliku dyke swarm, and pointed out the presence of chocolate-coloured trachytic rocks and breccias which were suggested to represent the remains of supracrustal rocks that once covered the area. Jones (1980) recorded the presence of trachytic lavas and breccias in the Motzfeldt area, and suggested that they represented xenoliths within the North Motzfeldt syenites. Emeleus and Harry (1970) mentioned pre-Motzfeldt and postMotzfeldt episodes of faulting, but did not identify the relationships of these events to North Motzfeldt.

Emeleus and Harry (1970) subdivided North Motzfeldt into two units, an earlier outer syenite, NM1, and a later central one, NM2, both of which consist of nepheline syenite. Subsequent studies of the region (e.g. Armour-Brown et al., 1983; Tukiainen et al., 1984; Tukiainen, 1988) have concentrated on mineral potential. In subsequent discussions, numbers refer to samples in the possession of one of the authors (AAF).

\section{Field description}

The North Motzfeldt centre is exposed in undulating high ground (average altitude $\sim 1250 \mathrm{~m}$ ) to the NW of Motzfeldt Sł. The frequency and severity of catabatic winds from the Greenland Ice cap (often gusting to $160 \mathrm{kph}$ ) makes scientific study in this area difficult. Permanent snow covers much of the area. Three prominent peaks within the centre rise above the moraine, forming a line of summits at 1350,1380 and $1300 \mathrm{~m}$ elevation (Fig. 2). The $1300 \mathrm{~m}$ summit is a prominent feature comprising Eriksfjord formation trachytes that weather to a chocolate-brown colour (Fig. 3) and this peak warrants mention as a notable landmark. The vast majority of the area studied is covered by shattered rock, and exposures of solid geology are restricted to glaciated valley walls and occasional breaks in the regolith cover. Many valley walls are only accessible with great difficulty, although ascent of some important vertical sections has been achieved in the present study. Thin veneers of shattered rock, which characterize many areas within North Motzfeldt, provide indirect field evidence. In many places, in situ brecciation and disturbance of bedrock appears to have occurred, and, although material can be locally disorientated, actual transport of material is restricted to a few metres. The continuity of Gardar dykes across the landscape identifies such regolith and allows inference of the solid geology beneath. The chronology of events in the North Motzfeldt area is given in Table $1 b$ and discussed in greater detail below. The field relationships of the area studied are given in Fig. 2.

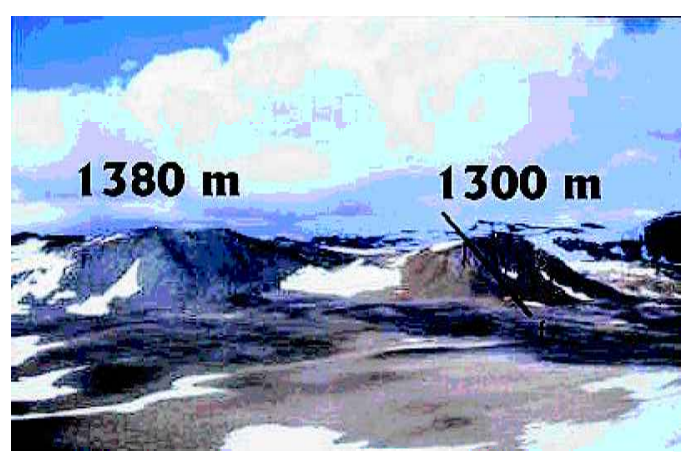

FIG. 3. View across the North Motzfeldt Centre, looking NE. The location of the viewer is close to the SE corner of Fig. 2. The peak on the left (NW) is the $1380 \mathrm{~m}$ summit comprising white NM2 syenite. The prominent brown-weatherin g peak of $1300 \mathrm{~m}$ is on the right (SE) of the picture. The $1300 \mathrm{~m}$ summit comprises a downfaulted block of Eriksfjord trachytes, believed to represent the roof zone. The approximate line of the fault is shown on the photograph as _ $\mathrm{f}$ and the downfaulted block is to the right (SE). Much of the foreground comprises recent glacial till. 


\section{Ketilidian basement}

To the $\mathrm{N}$ and $\mathrm{W}$ of the North Motzfeldt syenites, the Ketilidian rocks are coarse-grained hornblende granodiorites (the "late granites" of Allaart, 1976) with plagioclase and alkali feldspar phenocrysts up to $10 \mathrm{~mm}$ across, and oikocrysts of biotite and/or chlorite. In exposure, the rocks have a characteristic buff weathering, which contrasts with the pink-weathering Gardar rocks. To the $\mathrm{S}$ of the area studied, the basement is a pink granite sensu stricto, and the area to the $\mathrm{E}$ is underlain by basic plutonic rocks, all of Ketilidian age (Allaart, 1976).

\section{Eriksfjord supracrustal rocks}

The oldest Gardar rocks in the area are lavas interbedded with arenites which together comprise the Eriksfjord formation. These rocks were deposited onto a palaeosurface of Ketilidian rocks and the unconformity represents an important stratigraphic horizon. Although some fine-grained igneous rocks amongst the Eriksfjord succession may be sills, the widespread occurrence of vesicles and breccias suggests that many are truly extrusive. Eriksfjord volcanics at the base of the succession (immediately adjacent to North Motzfeldt intrusive rocks) comprise feldspar-phyric and aphyric trachytes and phonolites with few basic rocks in a sequence $\sim 10 \mathrm{~m}$ thick. The trachytes and phonolites are fine-grained pink rocks with some calcite, fluorite and quartz veins. Breccias are present in places, and consist of fragments of igneous rock cemented by carbonate. Above these evolved igneous rocks is a thick succession of cross-bedded arenites with occasional grits, giving way to a succession of more basic volcanic rocks which comprise the $1610 \mathrm{~m}$ summit (Larsen and Tukiainen, 1985). The Eriksfjord Formation in the North Motzfeldt area today represents small remnants of a succession that may have covered much of the Gardar.

The subhorizontal unconformity between the Eriksfjord and the Ketilidian basement is well exposed W of the $1350 \mathrm{~m}$ peak, where Eriksfjord arenites and trachytes rest on Ketilidian rocks. The unconformity has provided a sub-horizontal décollement which recent glaciation has exploited to give a terrain of isolated pockets of Eriksfjord rocks resting on the Ketilidian. The current land surface in many cases may therefore be partly coincident with the Eriksfjord palaeosurface. Volcaniclastic breccias cemented by a basic matrix, presumably representing Eriksfjord diatremes, exist in Ketilidian rocks to the $\mathrm{W}$ and $\mathrm{S}$ of the North Motzfeldt syenites (Emeleus and Harry, 1970) - a third diatreme was identified to the NE during the present study. Breccias cemented by trachyte have also been identified within trachyte Eriksfjord eruptives to the NE of the $1300 \mathrm{~m}$ summit. Since the form of the outcrop is difficult to constrain, these breccias may either be diatremes or conformable pyroclastic deposits within the Eriksfjord sequence. The diatreme to the $\mathrm{W}$ of the centre is notable since it contains significant numbers of carbonatite clasts and a xenolith assemblage that includes rocks that may be of lower crustal or mantle origin.

The Eriksfjord sequence in North Motzfeldt was classified as part of the Majût and Mussartût members by comparing stratigraphies (Poulsen, 1964), of which the Mussartût member is correlated with the Qassiarsuk (previously spelt Qagssiarssuk) volcanics to the SW (Andersen, 1997). The Qassiarsuk volcanics are characterized by the presence of ultramafic and carbonatite extrusives, and Qassiarsuk ultramafics appear to correlate with similar rocks in the North Motzfeldt region (Larsen and Tukiainen, 1985). Recognizable carbonatite tuffs have not yet been reported in the North Motzfeldt Eriksfjord sequence, although the presence of carbonatite clasts in one of the Eriksfjord diatremes indicates carbonatite magmatism in the area. Within the Eriksfjord sequence at both Qassiarsuk and North Motzfeldt are white, cross-bedded arenites that may have formed through erosion of Ketilidian granite and subsequent sedimentation in the rift basin. The arenites are conformable with the lavas. Thermal metamorphism of these arenites by the Gardar intrusive igneous centres does sometimes gives rise to garnet-bearing (presumably grossular) metaquartzite, indicating significant $\mathrm{Ca}$ in the system. This Ca may be secondary, introduced by hydrothermal activity associated with the plutonism, or alternatively it may result from detrital calcite introduced by the reworking of carbonatite tuffs.

\section{North Motzfeldt syenites}

The North Motzfeldt syenites crop out in a subcircular area of $\sim 4 \mathrm{~km}$ diameter. Detailed petrography is given below; only features visible in hand specimen are described in this section. The earliest unit is nepheline syenite, termed $\mathrm{NM} 1$, found in the $\mathrm{W}$ and $\mathrm{N}$ of the study area. 
NM1 syenites are white and equigranular, with small $(\sim 1 \mathrm{~mm})$ interstitial nepheline crystals between alkali feldspar laths, which have aspect ratios of $\sim 2$ or 3 . Some weak feldspar alignment is occasionally observed. Mafic minerals include interstitial amphiboles up to $3 \mathrm{~mm}$ long. NM1 is pink in areas believed to have experienced appreciable hydrothermal activity, and sometimes develops pegmatitic and aplitic facies. Near to the northern contact with the Ketilidian basement, a porphyritic contact facies is observed. It seems likely that NM1 originally extended further to the $\mathrm{W}$ but has been obliterated by younger activity. A pegmatite-rich facies of NM1 is observed in the $\mathrm{NE}$ of the current exposure.

In the $\mathrm{W}$, a younger nepheline syenite has intruded and brecciated NM1. This second unit (NM2) is a white or pink nepheline syenite characterized by pegmatite patches, typically $3 \mathrm{~cm}$ across (but sometimes up to $10 \mathrm{~cm}$ ), evenly distributed throughout the rock. Pegmatitic patches in syenite are developed elsewhere in the Igaliku complex, notably at margins of units and in the SI6 unit of the Illerfissalik (previously spelt Igdlerfigssalik) centre (Emeleus and Harry, 1970). The pegmatite patches comprise platy alkali feldspars up to $5 \mathrm{~cm}$ long with aspect ratios between 5 and 10, together with interstitial nepheline and amphibole, and pink zeolite filling anhedral, interstitial areas. The normal syenite is similar but finer grained and without zeolite. In these finer-grained syenites, amphibole occurs both as a primary phase and as overgrowths on pyroxene. Occasionally, an aplitic facies is found at the centre of pegmatitic patches. NM2 also forms a porphyritic contact facies, which is especially well developed near the eastern contact with NM1. Pink, hydrothermally altered variants are more common than in NM1. In addition to pegmatitic patches, discrete pegmatite and aplite veins are developed, with a similar mineralogy.

Significant microsyenitic sheeting took place in North Motzfeldt after the emplacement of NM2. Vertical sheets of microsyenite cut both NM1 and NM2 at their mutual contact in the eastern part of the centre. These vertical sheets form a $3 \mathrm{~km}$ long feature in the eastern part of the North Motzfeldt centre. The composition of the microsyenites is varied, and many are rich in accessory minerals, including eudialyte. A small $\left(1 \mathrm{~m}^{2}\right)$ enigmatic exposure of lamprophyre is present in the NW of the complex and may have formed during this stage of North Motzfeldt activity.
At the NE edge of the centre, a $40 \times 100 \mathrm{~m}$ body of white-weathering augite microsyenite (NM3) intrudes the contact between NM2 and the Ketilidian basement. This cuts all previous rocks (including the lamprophyre and nepheline microsyenites), and a single small $(4 \mathrm{~cm})$ metasomatized xenolith of an equigranular syenite reminiscent of NM1 has been found. NM3 syenite contains white alkali feldspar and dark aegirine-augite phenocrysts, and is texturally very varied. Some areas have highly aligned crystals whereas in others crystallization appears to have taken place under relatively quiescent conditions, and amphiboles form radiate crystals up to $4 \mathrm{~mm}$ long.

The roof to North Motzfeldt is preserved in the $\mathrm{S}$ of the study area where NM2 syenites have a subhorizontal contact with Eriksfjord volcanics the Eriksfjord-Ketilidian unconformity appears to have provided a plane beneath which North Motzfeldt magmas ponded. It may be that the magmas ponded at this level and were chilled against the supracrustal rocks above. The pegmatitic nature of NM2 may suggest the roof was water-saturated at the time of emplacement. Isolated exposures of what are interpreted as Eriksfjord trachytes up to $100 \mathrm{~m}$ across, occur within syenite blockfields, particularly in the NW of the centre. In the field, it is very difficult to distinguish with certainty the Eriksfjord rafts from frost-shattered trachyte dykes of the Igaliku dyke swarm. However, Eriksfjord rafts are obvious in the glaciated walls of Motzfeldt Sł which cut through the adjacent Motzfeldt syenites and we infer that similar processes occurred at North Motzfeldt. As with the Ketilidian, recent glaciation may have exploited the contact between the Eriksfjord and the syenites beneath, creating a land surface that is consistently within metres of the roof and preserving proximal xenoliths and/or roof pendants. Hydrothermal veins containing fluorite, calcite and quartz are relatively common in the basement and Eriksfjord rocks but are uncommon within the syenites.

\section{Motzfeldt centre}

Rocks of the Motzfeldt centre were intruded after the emplacement of North Motzfeldt and the contact between the two units is exposed in slabs in the SE of the study area (Fig. 2). Pinkweathering Motzfeldt syenites (termed "SM1" by Emeleus and Harry, 1970 and the "Motzfeldt Sł marginal facies" by Tukiainen, 1988) are distinguishable from white NM2, characterized by its 


\section{A. A. FINCH ETAL.}

development of patchy pegmatites. White xenoliths of NM2 up to $30 \mathrm{~m}$ long can be recognized within the pink Motzfeldt syenite. The Motzfeldt syenite is sporadically very patchy, showing variation in grain size. For example, feldspars range from $1-2 \mathrm{~mm}$ in some areas to $>3 \mathrm{~cm}$ in others over distances of a few metres. Significant rheomorphism and assimilation of North Motzfeldt syenite is inferred. The contact between the two syenites is oriented NE-SW where exposed, and appears subvertical. Although the plan map of the centre (Fig. 2) seems to indicate a finger of NM2 extending into the Motzfeldt centre, it should be stressed that this is largely an artefact of relief. The Eriksfjord rocks in the $\mathrm{S}$ of the study area form a cap on top of the syenites and we infer that the syenites extend further beneath this subhorizontal roof. Much of the middle and the $\mathrm{W}$ of the centre is covered by till.

\section{Gardar dykes}

Various dykes including porphyritic and aphyric basalts/dolerites, trachytes and phonolites cut the North Motzfeldt syenites.

The majority of dykes trend between 45 and $60^{\circ}$, and are attributed to the Igaliku Dyke Swarm as described by Upton and Emeleus (1987) and Pearce and Leng (1996). They include green trachytes with spectacular devitrification textures, especially at margins, and spherules up to $1 \mathrm{~cm}$ in diameter. Dolerite dykes are also common, and sometimes show radial growth textures, centred on small $(\sim 2 \mathrm{~mm})$ plagioclase phenocrysts. Some dolerites are characterized by large numbers of plagioclase xenocrysts up to $20 \mathrm{~cm}$ long (the "Big Feldspar Dykes" of Emeleus and Upton, 1976). The subparallel nature of the Igaliku dykes makes determining relative ages difficult, but a plagioclase-phyric dolerite (AF/96/199) cuts a porphyritic green trachyte $(\mathrm{AF} / 96 / 120)$ near to the contact of NM1 and NM2 (Fig. 2). Dyke widths in the study area vary from a few $\mathrm{cm}$ to $\sim 20 \mathrm{~m}$, and traceable lengths vary from tens of metres to kilometres. A swarm of thin (up to $10 \mathrm{~cm}$ wide) green aphyric trachyte dykes cuts NM syenites, but does not follow the typical trend, and may be older than the Igaliku dyke swarm. These dykes are characterized by a roughly ENE-WSW trend but meander, apparently exploiting local weaknesses within the host syenite. It is inferred that these dykes predate the majority of the Gardar dykes and were emplaced under a general WNW-ESE crustal tension.

\section{Late-Gardar faulting}

Faulting is difficult to observe due to poor exposure over many parts of the study area. Sinistral E-W wrench faults, such as the Flinks Dal Fault (Tukiainen, 1988), have influenced much of the area around North Motzfeldt with throws measured in $\mathrm{km}$. An E-W fault subparallel to the Flinks Dal fault can be demonstrated to offset the boundary of the centre in the $\mathrm{E}$ by $\sim 0.5 \mathrm{~km}$. This fault may dissect the entire centre beneath the till cover and extend down to Motzfeldt Sł along the river valley that drains North Motzfeldt. A NW-SE-faulted contact is inferred between NM2 and Eriksfjord rocks beneath the $1300 \mathrm{~m}$ summit (Fig. 2). The N-S and $\mathrm{E}-\mathrm{W}$ faults offset the boundary between basement and NM1 in the NE and north of the area. The former has an apparent vertical displacement of tens of metres and the latter have similar horizontal offsets. The discontinuous nature of some prominent dykes (e.g. to the $\mathrm{S}$ of the large lake) may indicate complex E-W faulting, with displacement of a horizontal component of the order of tens of metres and unknown vertical component.

\section{Siting and emplacement of the North Motzfeldt centre}

North Motzfeldt lies at the northeasternmost limit of the exposed area of the Gardar rift; further to the NE, exposure is lost beneath the inland ice. The Younger Giant Dyke Complex to the NW extends under the inland ice, and a continuation of Gardar rocks out to the NE is speculated. However, examination of till in the North Motzfeldt (the present study) and GF Holm Nunataq regions (B.G.J. Upton, pers. comm., 1997) has failed to demonstrate the presence of large volumes of plutonic Gardar rocks, although augite syenite erratics are recorded from Storelv valley to the $\mathrm{N}$ of the present study area (C.H. Emeleus, pers. comm., 2001). The balance of probability is therefore that the current exposure lies close to the local NE extent of Gardar plutonism. The identification of Gardar-age syenite $100 \mathrm{~km}$ to the $\mathrm{SE}$ on the East Coast of Greenland at Paatusoq Fjord (Grocott et al., 1999) may indicate that the Gardar rift is offset in a left-lateral sense by a structure currently underneath the inland ice.

North Motzfeldt is sited across an intrusive boundary between two units of the Ketilidian basement and it is inferred that this structural weakness allowed the ascent of the North 
Motzfeldt magmas. There is no evidence for synplutonic deformation in either Gardar or Ketilidian rocks, and emplacement possibly took place by passive stoping of blocks - this is supported by the presence of Ketilidian and Eriksfjord rafts and xenoliths in syenite in the NW of the centre. Field evidence demonstrates that the upward ascent of magma was impeded by the overlying Eriksfjord formation, and that the magma ponded at the Eriksfjord-Ketilidian unconformity. The current exposure of the whole of the North Motzfeldt centre is just beneath the roof zone and is consistent with the pegmatitic, volatile-rich nature of NM2. Emplacement of Gardar intrusives against the Eriksfjord-Ketilidian unconformity has been suggested for other Gardar centres (e.g. Upton and Fitton, 1985).

\section{Petrology of the North Motzfeldt syenites}

NM1 and NM2 are coarse-grained nepheline syenites, as described above. Feldspar in these rocks is idiomorphic microperthite although occasional cryptoperthitic relicts may be present in a few samples. Feldspar crystals exhibit varying degrees of hydrothermal alteration expressed as both turbidity (i.e. a loss of transparency in the crystal) and sericitization (i.e. alteration to high-birefringence white micas). The products of hydrothermal alteration occur both as clearly defined veins and as pervasive areas of alteration. Some replacement of $\mathrm{K}$-feldspar by albite is observed in coarse microperthites. Nepheline is more abundant in NM2, but is present in both units. It is present most commonly as interstitial crystals, although euhedral nephelines sometimes occur. In most samples, nepheline has been altered to intimate intergrowths of zeolites and white mica, termed 'gieseckite'. Alteration of nepheline to sodalite and possibly cancrinite is also widespread.

Mafic minerals in NM1 and NM2 include amphibole, pyroxene and biotite mica. Pyroxene is yellow to yellow-green augite. In some rocks, the pyroxenes have irregular green rims where late-stage enrichment of $\mathrm{Na}$ gives rise to aegirineaugites. Mantling of pyroxene by amphibole is common - in some cases prominent cleavages are continuous through both phases indicating that the amphibole is secondary. Amphibole also occurs as crystals with brown to yellow-green pleochroism, sometimes with irregular green, sodic rims ( $c f$. pyroxene). Small grains of dark ferroan biotite are also present as an alteration product around pyroxene. Primary mica is not present. Opaque ilmenomagnetite is widespread and associated in clusters with, or mantled by, mafic minerals. The most common accessory mineral is euhedral apatite, found enclosed within mafic minerals in all of the units. Zircons form small euhedral tetragonal prisms, along with titanite in NM2. Rare element-rich accessory minerals are widespread in both units, including rinkite- $\mathrm{m}$ sandrite and låvenite, (see Jones and Larsen, 1985, for a description of these minerals in a nepheline-syenite setting).

The microsyenites that post-date NM2 are nepheline-bearing, often with significant pyroxene and eudialyte $(20-40 \%$ in both cases); some samples have a sodic amphibole. Fluorite and rinkite-mł sandrite plus other rare minerals dominate the accessory mineralogy. The term 'white lujavrite' is applied to some agpaitic, eudialyte nepheline microsyenites in which felsic minerals dominate over mafic ones. Such rocks are already reported from the Igaliku Complex (e.g. the SM6 unit of Motzfeldt; Jones and Larsen, 1985) and they have a prominent mineral alignment, believed to arise from crystal settling under very low viscosities during emplacement. However, the microsyenite at North Motzfeldt has a granular texture without obvious mineral alignment, in contrast to most lujavrites. This unusual unit is the subject of further study. The much larger augite microsyenite of NM3 is texturally and mineralogically distinct from all other units, having little nepheline and eudialyte.

\section{Analytical methods}

Major and trace element concentrations were determined by X-ray fluorescence (XRF) at the Department of Geology \& Geophysics, University of Edinburgh, following the method described by Fitton et al. (1988). Rb-Sr isotopic data were determined by mass spectrometry in the Laboratory of Isotope Geology, MineralogicalGeological Museum, Oslo, following the method described by Andersen (1997). The error on ${ }^{87} \mathrm{Sr} /{ }^{86} \mathrm{Sr}$ quoted is based on replicate analyses of NBS 987, which gives $0.710208 \pm 0.000043$.

\section{Geochemical variation in the North Motzfeldt complex}

North Motzfeldt rocks show fairly uniform major element geochemistry, with no distinct variations between the three units (Table 2). All the more 
evolved Gardar rocks analysed in this study, including nepheline syenites of the North Motzfeldt centre, alkaline dykes, and trachytic lavas of the Eriksfjord formation, form a tight cluster on a total alkalis vs. silica diagram (Fig. 4) and generally have similar major element geochemistry to other nepheline syenites in the Gardar (e.g. Jones, 1980; Goodenough, 1997). The $\mathrm{Zr} / \mathrm{Nb}$ ratios are consistently low for all the Gardar rocks analysed in this study, ranging between 2.4 and 5.1, with the exception of one trachyte dyke (AF/96/103) which has a $\mathrm{Zr} / \mathrm{Nb}$ ratio of 7.3. This dyke may belong to the extensive "high $\mathrm{Zr} / \mathrm{Nb}$ " group of dykes described by Pearce and Leng (1996), which cut the Gardar central complexes and are not genetically related to them. $\mathrm{Zr} / \mathrm{Nb}$ ratios of $\sim 4$ are characteristic of rocks derived from an OIB-like source (Fitton et al., 1988). The Ketilidian granites have much higher $\mathrm{Zr} / \mathrm{Nb}$ ratios of between 13.9 and 18.1 , correlating with the subduction-related origin for these granites suggested by Chadwick and Garde (1996). The low $\mathrm{Zr} / \mathrm{Nb}$ ratios for all the Gardar rocks suggest that crustal contamination has had a minimal effect on the mantle-derived magmas of the North Motzfeldt Complex.

Primitive mantle-normalized spidergrams for selected samples from the rocks of the North Motzfeldt Centre are shown in Fig. 5. The patterns are generally similar for samples from all three syenite units, although a wide variation in $\mathrm{Ba}$ and $\mathrm{Sr}$ contents is seen. This variation is probably related to alteration of feldspar by hydrothermal fluids (recognized as turbidity and sericitization of feldspar in thin-section), rather than to a primary magmatic effect. It is notable that samples of Eriksfjord lavas from this area are essentially indistinguishable from the North Motzfeldt syenites in terms of both major and trace element geochemistry. This is consistent with a previous suggestion (Jones, 1980) that Eriksfjord lavas in this area are genetically related to local plutonism.

Figure 6 shows spidergram patterns for selected samples of dykes from the North Motzfeldt area. The lamprophyre can be seen to have a fairly flat pattern, with a slight upturn at $\mathrm{Nb}$ and a distinct trough at Sr. This pattern is similar to that for lamprophyre dykes from elsewhere in the Igaliku Dyke Swarm (Pearce and Leng, 1996). Two examples of trachytic dykes are shown in the figure. Sample AF/96/25 has a similar pattern to samples of the North Motzfeldt syenites and may represent an offshoot from the main complex. Sample AF/96/103, however, clearly differs in terms of trace-element geochemistry from the rocks around it, with elevated contents of incompatible elements (particularly $\mathrm{Nb}$ ). This pattern is almost identical to that for the more evolved rocks of the Igaliku Dyke Swarm shown

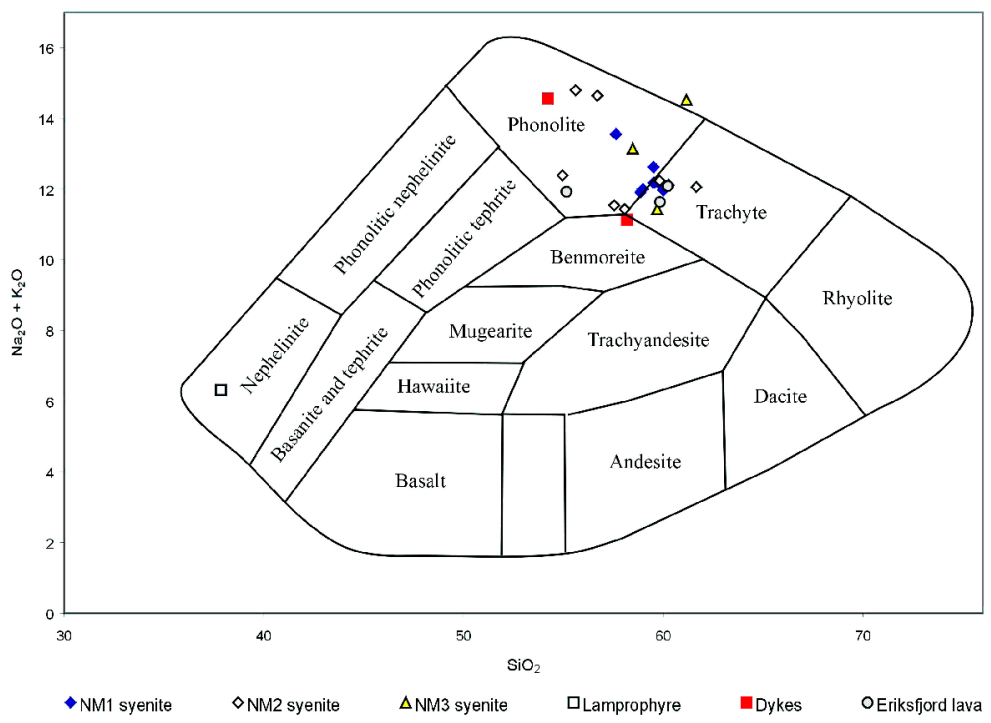

FIG. 4. Alkali-silic a diagram for the lithologies in the North Motzfeldt area. 


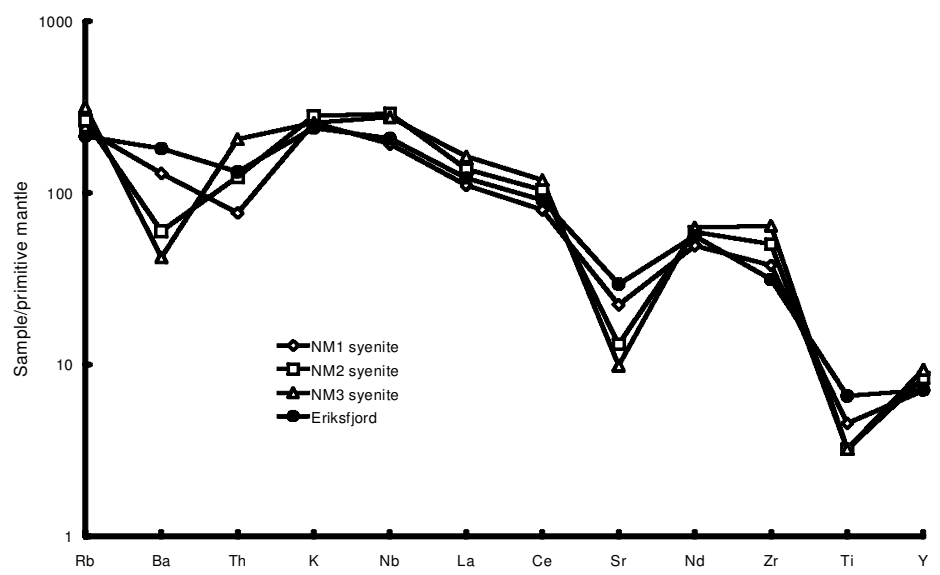

FIG. 5. Spidergrams for the syenite units at North Motzfeldt and Eriksfjord trachyte normalized to primitive mantle (McDonough and Sun, 1995).

by Pearce and Leng (1996), and is also similar to that for trachytic dykes from the Ivittuut (Ivigtût) area in the western part of the Gardar province (Goodenough, 1997), suggesting that this is part of a more extensive dyke swarm.

The preliminary geochemical evidence fits with a model for essentially two magmatic groups in the North Motzfeldt area. The major group includes the syenites of the North Motzfeldt Centre itself and the overlying Eriksfjord trachytes, which may be genetically related. Following the emplacement of the syenites, dykes of varying compositions, unrelated to the syenites, were intruded. Some of these dykes, including the lamprophyres, may belong to the localized Igaliku Dyke Swarm; others, including trachytes and dolerites, are part of a more extensive group of Gardar dykes.

\section{Age of North Motzfeldt}

The age of North Motzfeldt has previously been estimated by cross-cutting relationships with the Motzfeldt syenites, dated as Early Gardar $(1282 \pm 30 \mathrm{Ma})$ using a $\mathrm{Rb}-\mathrm{Sr}$ whole-rock isochron (Blaxland et al., 1978, recalculated using new decay constants), and at $1350 \pm 10 \mathrm{Ma}$ using $\mathrm{U}-\mathrm{Pb}$ techniques on

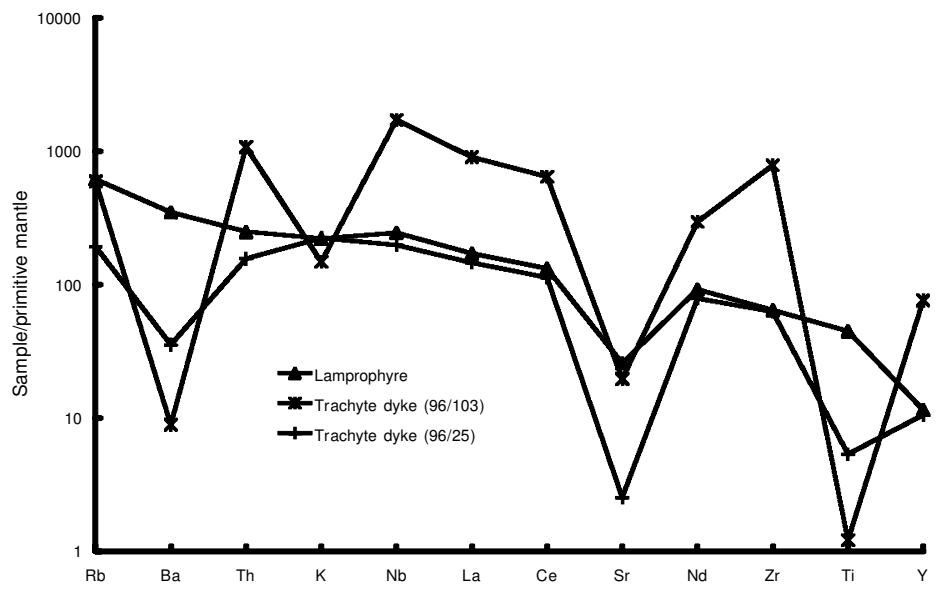

FIG. 6. Spidergrams of other lithologies normalized to primitive mantle (McDonough and Sun, 1995). 
apatite (Paslick et al., 1993). North Motzfeldt predates the SM1 unit as defined by Emeleus and Harry (1970), originally considered to be the oldest unit of the Motzfeldt centre. North Motzfeldt syenites would therefore be among the oldest rocks in the Gardar province.

Initial $\mathrm{Sr}$ isotopic data, with absolute $\mathrm{Rb}$ and $\mathrm{Sr}$ values taken from whole-rock and mineral separates from all NM units, are presented in Table 3. Figure 7 is a preliminary isochron based on these data, assuming an error in $\mathrm{Rb} / \mathrm{Sr}$ of $0.5 \%$ and $0.006 \%$ in ${ }^{87} \mathrm{Sr} /{ }^{86} \mathrm{Sr}$. The slope from this suggests a $\mathrm{Rb}-\mathrm{Sr}$ radiometric age of $1226 \pm 27 \mathrm{Ma}$ for North Motzfeldt (a model-3 age MSWD = 2.6 using ISOPLOT 2.49; Ludwig, 2001). All the units of North Motzfeldt appear synchronous within error. A robust regression (Ludwig, 2001) on the same data gives an age of $1225_{-39}^{+30} \mathrm{Ma}$, which is indistinguishable from the model-3 answer. Although more precise radiometric studies may refine this date, it is a Mid-Gardar age and clearly younger than the Early Gardar ages obtained from Motzfeldt using both the U-Pb and $\mathrm{Rb}-\mathrm{Sr}$ systems.

The new Mid-Gardar radiometric age for North Motzfeldt is problematic since our field evidence suggests strongly that North Motzfeldt is older than the Motzfeldt syenites, considered previously to be Early Gardar in age. We have considered carefully whether rheomorphism, and the relatively localized exposures in which the contact region is found, may have produced field exposures in which the relative ages of the various components are ambiguous. We believe that the field evidence indicates that North

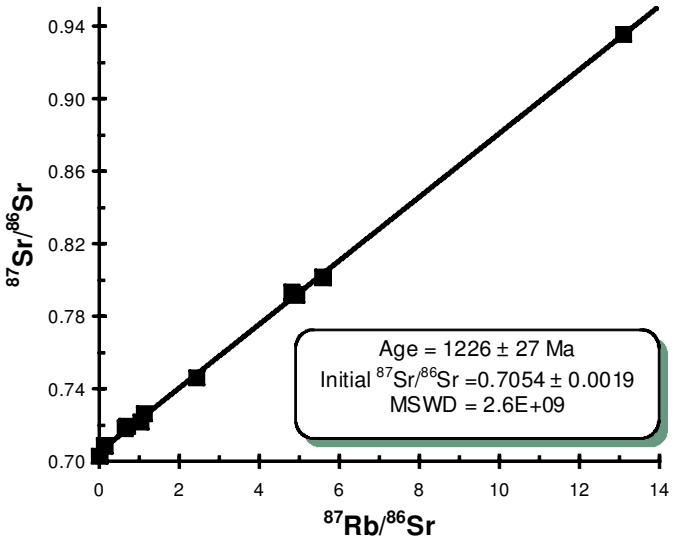

FIG. 7. Rb-Sr isochron age of NM units (calculated using Model-3 solution: Ludwig, 2001).

Motzfeldt is the older centre, and therefore we have no alternative but to look carefully at the radiometric age for the Motzfeldt centre. The published $\mathrm{Rb}-\mathrm{Sr}$ isochron date for Motzfeldt (Blaxland et al., 1978) has a very large standard deviation compared with other Gardar centres. Interestingly, the residuals from the Motzfeldt isochron of Blaxland et al. (1978) are greatest for samples collected $\mathrm{N}$ of Motzfeldt Sł lake suggesting either that these samples have significant different initial isotopic ${ }^{87} \mathrm{Sr} /{ }^{86} \mathrm{Sr}$ ratios, or that rocks of different ages have been considered together. If samples N of Motzfeldt Sł lake are omitted, a more robust $\mathrm{Rb}-\mathrm{Sr}$ isochron age of $1287 \pm 4 \mathrm{Ma}$ is obtained, indistinguishable from the slope of the original isochron but

TABle 3. Rb-Sr isotopic data for the North Motzfeldt centre.

\begin{tabular}{lrrrrrrr}
\hline Sample number & $\mathrm{Rb} p \mathrm{pm}$ & $\pm 2 \sigma$ & $\mathrm{Sr} p \mathrm{ppm}$ & $\pm 2 \sigma$ & ${ }^{87} \mathrm{Sr} /{ }^{86} \mathrm{Sr}$ & $\pm 2 \sigma$ & ${ }^{87} \mathrm{Rb} /{ }^{86} \mathrm{Sr}$ \\
\hline $\mathrm{AF} / 96 / 29$ WR & 58.51 & 0.02 & 1336.64 & 0.01 & 0.708609 & 9 & 0.12667 \\
$\mathrm{AF} / 96 / 23$ WR & 109.92 & 0.28 & 493.26 & 0.01 & 0.718274 & 9 & 0.64541 \\
$\mathrm{AF} / 96 / 17$ WR & 183.59 & 0.17 & 95.85 & 0.00 & 0.801446 & 9 & 5.59258 \\
$\mathrm{AF} / 96 / 123$ WR & 152.86 & 0.04 & 430.08 & 0.07 & 0.721679 & 88 & 1.02968 \\
$\mathrm{AF} / 95 / 101$ WR & 188.87 & 0.08 & 793.73 & 0.01 & 0.719476 & 8 & 0.68924 \\
$\mathrm{AF} / 96 / 124$ FSP & 221.18 & 0.08 & 49.92 & 0.00 & 0.935548 & 11 & 13.10436 \\
$\mathrm{AF} / 96 / 17$ FSP & 197.53 & 0.03 & 116.83 & 0.00 & 0.791851 & 10 & 4.93195 \\
$\mathrm{AF} / 95 / 101$ FSP & 213.15 & 0.75 & 549.72 & 0.01 & 0.726353 & 10 & 1.12387 \\
$\mathrm{AF} / 95 / 101$ APAT & 8.41 & 1.67 & 9618.92 & 0.00 & 0.702901 & 15 & 0.00253 \\
$\mathrm{AF} / 96 / 124$ AMPH & 32.12 & 0.03 & 19.50 & 0.00 & 0.793212 & 10 & 4.80645 \\
$\mathrm{AF} / 96 / 17$ AMPH & 14.79 & 0.05 & 17.63 & 0.00 & 0.746078 & 9 & 2.43687
\end{tabular}

$\mathrm{WR}=$ whole-rock $;$ FSP $=$ alkali feldspar separate $;$ APAT $=$ apatite separate, AMPH $=$ amphibole separate 
providing errors more typical of data from other centres. Since some parts of the Motzfeldt centre yield Early Gardar ages, whereas in our field area, Motzfeldt is apparently younger than $\sim 1226 \mathrm{Ma}$, one explanation is that rocks currently described as 'Motzfeldt' comprise more than one period of magmatism. We tentatively suggest the terms 'Early' and 'Late' Motzfeldt to distinguish these separate periods - Early Motzfeldt magmatism was Early Gardar in age (including the Flinks Dal formation of Tukiainen, 1988) and Late Motzfeldt, which includes the Motzfeldt Sł formation (Tukiainen, 1988), is younger than North Motzfeldt. Certainly, elsewhere in the Igaliku complex, the syenites of the Illerfissalik centre were intruded with a significant hiatus in magmatism, since the Igaliku dyke swarm was intruded between the emplacement of the SI3 and SI4 units.

A Mid-Gardar age for North Motzfeldt is consistent with the proposed correlation between the Eriksfjord sequences of North Motzfeldt and Qassiarsuk (Poulsen, 1964). The Qassiarsuk volcanics are dated at $1205 \pm 12 \mathrm{Ma}$ by a $\mathrm{Rb}-\mathrm{Sr}$ isochron and at $1176 \pm 8 \mathrm{Ma}$ by a whole-rock $\mathrm{Pb}$ $\mathrm{Pb}$ isochron (Andersen, 1997). North Motzfeldt is clearly younger than the Eriksfjord rocks in its roof. Our new age is within error of the date of the Qassiarsuk volcanics and consistent with the suggestion that the North Motzfeldt centre and the associated Eriksfjord rocks are of similar ages.

The intercept of the isochron gives an estimate of the ${ }^{87} \mathrm{Sr} /{ }^{86} \mathrm{Sr}$ initial ratio for the North Motzfeldt centre as $0.7054 \pm 0.0019$. This value is typical of the initial ratios of other Gardar centres (Blaxland et al., 1978). The Gardar mantle is believed to have a $\mathrm{Sr}$ initial ratio of $\sim 0.7033$, and the somewhat larger North Motzfeldt value hints at interaction with a more $\mathrm{Sr}$ radiogenic component, presumably the Ketilidian crust, sometime during the evolution of the centre. This might be via crustal assimilation in the magmatic state, or hydrothermal interaction involving transport of elements from the host to the centre in the subsolidus. Further radiometric studies are required to reassess fully the chronology of NE Igaliku, and to deconvolute the various contributions to the radiogenic $\mathrm{Sr}$ signature.

\section{Geological significance}

North Motzfeldt is small in comparison with other Igaliku centres, and has been considered as a satellite intrusion to the larger Motzfeldt centre. Its proximity to the vast centres of Igaliku have meant that it has, to a large degree, been overlooked, whereas other small Gardar centres such as Klokken and Puklen are considered independent because of their isolated positions. North Motzfeldt has two significant features that make it of wider interest. First, the preservation of the roof at North Motzfeldt is unusual Ilimmaasaq (previously spelt Ilímaussaq) is the only other Gardar centre described in the literature in which a roof zone remains intact (Kunzendorf et al., 1982). However, the unique nature of the Ilimmaasaq magma makes it difficult to understand whether processes in the roof zone of Ilimmaasaq are typical of other, less extreme Gardar centres. North Motzfeldt retains parts of the roof but it has a more typical nepheline syenite composition, and so processes that occurred here are likely to be typical of roof zones in other silica undersaturated, subvolcanic centres. In addition, North Motzfeldt contains a small eudialyte nepheline microsyenite unit that may be lujavritic. Small lujavrite bodies are known from other Igaliku centres, including the SM6 unit of Motzfeldt (Jones and Larsen, 1985), and an unnamed unit from North Qooroq (Coulson, 1997). Peralkaline microsyenites are reported from other parts of Motzfeldt (Tukiainen, 1988). These are in addition to the substantial lujavrites of Ilimmaasaq (see Sł rensen, 1997) for a review). Although not volumetrically large, lujavrites emphasize the continuity between phonolitic and agpaitic magmas. Agpaitic magmas are believed to arise when the alkali content of peralkaline magmas exceeds threshold levels such that volatiles become retained by the magma and fractionation is prolonged. In addition, the role of impermeable roof zones in minimizing volatile loss is considered important. It is interesting to note that the Motzfeldt and North Qooroq lujavrites both occur beneath large country-rock xenoliths and at Ilimmaasaq, a metasomatized, but apparently impermeable roof is preserved. The North Motzfeldt eudialyte nepheline microsyenite is similarly developed close to the inferred roof.

The Rb-Sr isochron presented here (Fig. 7) demonstrates that North Motzfeldt is significantly younger than previously thought. Until now, North Motzfeldt and the Eriksfjord rocks in the roof were believed to be among the earliest Gardar rocks and much about the early development of the rift was inferred from them. Our data 
show that the North Motzfeldt centre, and much of the Late Motzfeldt complex next to it, is significantly younger. More radiometric age dating work in this area is required before the extent of Early ( 1300 Ma) Gardar magmatism in Igaliku can be properly delimited.

\section{Conclusions}

The North Motzfeldt nepheline syenite centre, although small, provides important information about the evolution of this part of the Gardar Province. Cross-cutting relationships with other Gardar igneous rocks are well displayed, and this allows us to constrain isotopic data. We suggest that the Motzfeldt centre was emplaced in a series of pulses, with possibly as much as $100 \mathrm{Ma}$ between the 'Early' and 'Late' Motzfeldt episodes. The North Motzfeldt Centre is a particularly clear example of a plutonic centre that has formed by ponding of magma beneath an impermeable layer, with subsequent accumulation of volatiles beneath this roof leading to the formation of unusual highly evolved magmas. Further study of the centre will be important in increasing our understanding of these important, rare-element rich rocks.

\section{Acknowledgements}

Fieldwork for the present study was carried out in the summers of 1995, 1996 and 1999. The Carnegie Trust for the Universities of Scotland, The Percy Sladen Trust, The Royal Geographical Society, The Mineralogical Society of Great Britain and Ireland, NERC and the University of Luton gave financial assistance for the present study. Radiometric studies formed part of a collaborative programme between AAF and TA funded by the British Council. We are grateful for the field assistance of Anders Stochholm (1996), Tara Smith and Kerry Hunter (1999).

\section{References}

Allaart, J.H. (1976) Ketilidian Mobile Belt in South Greenland. Pp. 120-51 in: Geology of Greenland (A. Escher and W.S. Watt, editors). Grł nlands Geologiske Undersł gelse, Copenhagen.

Andersen, T. (1997) Age and petrogenesis of the Qassiarsuk carbonatite-alkaline silicate volcanic province in the Gardar rift, South Greenland. Mineral. Mag., 61, 499-513
Armour-Brown, A., Tukiainen, T., Wallin, B., Bradshaw, C. and Emeleus, C.H. (1983) Uranium exploration in South Greenland. Rapport Grt nlands Geologiske Underst gelse, 115, 68-75.

Blaxland, A.B., van Breemen, O., Emeleus, C.H. and Anderson, J.G. (1978) Age and origin of the major syenite centres in the Gardar Province of South Greenland: Rb-Sr studies. Geol. Soc. Amer. Bull. 89, 231-44.

Chadwick, B., and Garde, A.A. (1996) Palaeoproterozoic oblique plate convergence in South Greenland: a reappraisal of the Ketilidian orogen. Pp. 179-96 in: Precambrian Crustal Evolution in the North Atlantic Region (T.S. Brewer, editor). Spec. Publ. 112. Geological Society, London.

Coulson, I.M. (1997) Post-magmatic alteration in eudialyte from the North Qôroq centre, South Greenland. Mineral. Mag., 61, 99-109.

Emeleus, C.H. and Harry, W.T. (1970) The Igaliko nepheline syenites, South Greenland. General description. Bull. Grt nlands Geologiske Underst gelse, 85, 116 pp. \{Also Meddr. Grtnland, 186.

Emeleus, C.H. and Upton, B.G.J. (1976) The Gardar Province of South Greenland. Pp. 152-81 in: Geology of Greenland (A. Escher and W.S. Watt, editors). Grł nlands Geologiske Undersł gelse, Copenhagen.

Finch, A.A. (1990a) The chemical and isotopic nature of fluids associated with alkaline magmatism, South Greenland. $\mathrm{PhD}$ thesis, Univ. Edinburgh, UK.

Finch, A.A. (1990b) Genthelvite and willemite, zinc minerals associated with late-stage alkaline residues, Motzfeldt centre, South Greenland. Mineral. Mag., 54, 407-12.

Finch, A.A., Parsons, I. and Mingard, S.C. (1995) Biotites as indicators of fluorine fugacities in fluids associated with alkaline magmatism, South Greenland. J. Petrol., 36, 1701-28.

Fitton, J.G., James, D., Kempton, P.D., Ormerod, D.S. and Leeman, W.P. (1988) The role of lithospheric mantle in the generation of late Cenozoic basic magmas in the Western United States. J. Petrol., Special Lithosphere Issue, 331-49.

Garde, A.A., Chadwick, B., Grocott, J., Hamilton, M., McCaffrey, K. and Swager, C.P. (1998) An Overview of the Palaeoproterozoic Ketilidian Orogen, South Greenland. ESCOOT - Lithoprobe Report, 68, 50-66.

Garde, A.A., Hamilton, M.A., Chadwick, B., Grocott, J. and McCaffrey, K.J.W. (2001) The Ketilidian orogen of South Greenland: tectonics, magmatism and forearc accretion during Palaeoproterozoi c oblique convergence. Canad. J. Earth Sci. (in press).

Goodenough, K.M. (1997) Geochemistry of Gardar 
intrusions in the Ivigtut area, South Greenland. $\mathrm{PhD}$ thesis, Univ. Edinburgh, UK.

Grocott, J., Garde, A.A., Chadwick, B., Cruden, A.R. and Swager, C. (1999) Emplacement of rapakivi granite and syenite by floor depression and roof uplift in the Palaeoproterozoi c Ketilidian orogen, South Greenland. J. Geol. Soc., 156, 15-24.

Jones, A.P. (1980) Petrology and structure of the Motzfeldt centre, Igaliko complex, South Greenland. PhD thesis, Univ. Durham, UK.

Jones, A.P. (1984) Mafic silicates from the nepheline syenites of the Motzfeldt centre, South Greenland. Mineral. Mag., 48, 1-12.

Jones, A.P. and Peckett, A. (1990) Zr-bearing aegirines from Motzfeldt, South Greenland. Contrib. Mineral. Petrol., 75, 251-5.

Jones, A.P. and Larsen, L.M. (1985) Geochemistry and REE minerals of nepheline syenites from the Motzfeldt centre, South Greenland. Amer. Mineral., 70, 1087-100.

Kunzendorf, H., Nyegaard, P. and Nielsen, B.L. (1982) Distribution of characteristic elements in the radioactive rocks of the northern part of Kvanefjeld, Ilímaussaq intrusion, South Greenland. Rapport Grt nlands Geologiske Underst gelse, 109.

Larsen, L.M. and Tukiainen, T. (1985) New observations on the Easternmost extension of the Gardar supracrustals (Eriksfjord formation), South Greenland. Rapport Grt nlands Geologiske Underst gelse, 125, 64-6.

Ludwig, K.R. (2001) Isoplot/Ex rev. 2.49. A Geochronological Toolkit for Microsoft Excel. Berkeley Geochronology Center Special Publication No 1a.

McDonough, W.F. and Sun, S.-S. (1995) The composition of the Earth. Chem. Geol., 120, 223-55.

Paslick, C.R., Halliday, A.N., Davies, G.R., Mezger, K. and Upton, B.G.J. (1993) Timing of Proterozoic magmatism in the Gardar Province, southern Greenland. Geol. Soc. Amer. Bull, 105, 272-8.

Pearce, N.J.G. and Leng, M.J. (1996) The origin of carbonatites and related rocks from the Igaliko Dyke Swarm, Gardar Province, South Greenland: field, geochemical and $\mathrm{C}-\mathrm{O}-\mathrm{Sr}-\mathrm{Nd}$ isotope evidence. Lithos, 39, 21-40.

Poulsen, V. (1964) The sandstones of the Precambrian Eriksfjord Formation in South Greenland. Rapport Grt nlands Geologiske Underst gelse, 2, 16 pp.

Sł rensen, H. (1997) Agpaitic rocks - an overview. Mineral. Mag., 61, 485-98.

Tukiainen, T. (1988) Niobium-tantalu m mineralisation in the Motzfeldt centre of the Igaliko Nepheline Syenite Complex, South Greenland. Pp. 230-46 in: Mineral Deposits within the European Community (J. Boissonnas and P. Omenetto, editors). SpringerVerlag, Berlin, Heidelberg.

Tukiainen, T., Bradshaw, C. and Emeleus, C.H. (1984) Geological and radiometric mapping of the Motzfeldt centre of the Igaliko Complex, South Greenland. Rapport Grt nlands Geologiske Underst gelse, 120, 78-83.

Upton, B.G.J. and Emeleus, C.H. (1987) MidProterozoic alkaline magmatism in Southern Greenland: The Gardar Province. Pp. 449-71 in: Alkaline Igneous Rocks (J.G. Fitton and B.G.J. Upton, editors). Spec. Publ. 30. Geological Society, London.

Upton, B.G.J. and Fitton, J.G. (1985) Gardar dykes north of the Igaliko syenite complex, Southern Greenland. Rapport Grt nlands Geologiske Underst gelse, 127, $24 \mathrm{pp}$.

\{Manuscript received 4 June 2001:

revised 2 October 2001\} 